Peopling the World 



\title{
PEOPLING THE WORLD
}

Representing Human Mobility from Milton to Malthus

\section{Charlotte Sussman}

\author{
$\overline{\text { PENN }}$ \\ UNIVERSITY OF PENNSYLVANIA PRESS


Copyright (C) 2020 University of Pennsylvania Press

All rights reserved. Except for brief quotations used for purposes of review or scholarly citation, none of this book may be reproduced in any form by any means without written permission from the publisher.

\author{
Published by \\ University of Pennsylvania Press \\ Philadelphia, Pennsylvania I9IO4-4II2 \\ www.upenn.edu/pennpress
}

Printed in the United States of America on acid-free paper

I 3579 IO 8642

Library of Congress Cataloging-in-Publication Data

Names: Sussman, Charlotte, author.

Title: Peopling the world: representing human mobility from Milton to Malthus / Charlotte Sussman.

Description: Ist edition. | Philadelphia: University of Pennsylvania Press, [2020] | Includes bibliographical references and index. |

Identifiers: LCCN 2019034599 | ISBN 9780812252026 (hardcover)

Subjects: LCSH: English literature-18th century-History and criticism. |

Emigration and immigration in literature. | Population in literature. |

Great Britain-Emigration and immigration-History-18th century. |

Great Britain-Population-History-I8th century. | Great

Britain-Colonies-History- 18 th century.

Classification: LCC PR448.E43 S87 2020 | DDC 820.9/355-dc23

LC record available at https://lccn.loc.gov/2019034599 
For Raoul 
